\title{
Economic Determinants of Sexual Debut among In-School Adolescents in Rural Kenya
}

\author{
Diana Kerubo Ondieki, Dalmas Ochieng Omia, Wanjiru Gichuhi, \\ Caroline Marygorety Akinyi Otieno
}

African Women's Studies Centre, University of Nairobi, Nairobi, Kenya

Email: ondiekidk@gmail.com

How to cite this paper: Ondieki, D. K., Omia, D. O., Gichuhi, W., \& Otieno, C. M. A. (2021). Economic Determinants of Sexual Debut among In-School Adolescents in Rural Kenya. Advances in Aplied Sociology, 11, 231-243.

https://doi.org/10.4236/aasoci.2021.115020

Received: April 13, 2021

Accepted: May 7, 2021

Published: May 10, 2021

Copyright $\odot 2021$ by author(s) and Scientific Research Publishing Inc. This work is licensed under the Creative Commons Attribution International License (CC BY 4.0).

http://creativecommons.org/licenses/by/4.0/

\begin{abstract}
Most people are driven by material gains and adolescents are no exception. We set to determine the influence of economic factors on sexual debut among in-school adolescents through the lens of the Marxist theory. A mixed-method design, quantitative and qualitative data collection methods, was used. Three sets of adolescents were targeted in the study: mixed-sex day secondary schools, girls-only boarding and boys-only boarding secondary schools, where, a sample of 400 (200 females and 200 males) aged 14 - 18 years were drawn for purposes of a quantitative survey. Focus group discussions (FGDs), Case Narratives and Key Informant interviews were used to collect qualitative data. The results indicate that $61 \%$ had ever had sex, more students (63.5\%) in mixed day schools had ever had sex compared to single sex schools (58.5\%). Male students were more likely to have ever had sex compared to female students $[\mathrm{OR}=1.59$ (95\% CI $0.83,1.85), p=0.03$ ]. Most of the students got spending money $(89 \%)$ and gifts $(60 \%)$ from their parents. However, those receiving gifts from boy/girlfriends had four times the odds of ever having sex (OR 4.04, 95\% CI 1.36 - 11.97). Qualitative data on the other hand revealed that the need for money for basic needs and also for pleasure played a significant role in early sexual debut among adolescents. In conclusion, the majority of the in-school adolescents in Nyamira county had ever had sex. Most students got sustenance from their parents, implying a high likelihood of a pluralist environment where peer pressure, cultural norming and popular culture on social and mainstream media also contributed to early sexual debut. Those with money were seen to have power over another's autonomy and a person's economic environment was seen to influence their decisions collaborating the Marxist theory.
\end{abstract}

\section{Keywords}

Adolescent, Economic, Sex, In-School 


\section{Introduction}

Sexual intercourse is commonly initiated during adolescence. Over the last decade, there has been an increase in the proportion of adolescents who report sexual activity at each year of age (Kastbom et al., 2015). Early sexual initiation is associated with adverse reproductive health outcomes such as unwanted adolescent pregnancies, sexually transmitted infections, cervical cancer and early marriages. When an adolescent begins to have sex, the path taken and the outcome depend on factors that can influence their behavior at each stage, that is, economic, socio-cultural and political factors (Glasier et al., 2006). (Dinkelman et al., 2008) showed that girls from poorer households were more likely to have ever had sex. In this study, for every $10 \%$ decrease in household income, the probability of having sex went up by $0.5 \%$. However, (Speizer et al., 2013) showed that adolescents from richer families relative to those from poor families were more likely to have ever had sex. In another study, it was noted that those who engaged in early sex did it mainly for gifts, cash and other favours (Ankomah et al., 2011).

Nyamira County has the fourth-highest burden of teenage pregnancy and motherhood in Kenya, 28\% against a national average of $18 \%$. Sexual debut in women ages 20 - 49 in Nyamira County is 17.1 years while for men in the same age group is 18.1 years, with the national average being 18.0 years and 17.4 years respectively (Kenya National Bureau of Statistics, 2015). Nyamira county is mainly an agricultural community, dealing mainly in tea and bananas (County Government of Nyamira, 2021). It has a huge population of approximately 600,000 people in a small area $\left(925 \mathrm{~km}^{2}\right)$. This study sought to evaluate whether economic factors led to sexual debut among in-school adolescents in this county in rural Kenya.

\section{Materials and Methods}

This study was conducted in Nyamira County located in the southwestern part of Kenya. Nyamira County has 5 sub-counties, but because of their homogeneity, the study was conducted in two sub counties-Manga and Nyamira South sub-counties. The study compared mixed day secondary schools, girls-only boarding secondary schools and boys-only boarding secondary schools. Students in mixed day secondary schools continually interact with the opposite sex both in and out of school. The initiators for sex are both in the school environment and the broader community. Students from boarding single-sex secondary schools, on the other hand, only get to interact with the opposite sex during interschool functions and when schools close for the holidays. Therefore, in the two subcounties, 2 mixed day secondary schools, 2 girls only boarding school and two boys only secondary schools were randomly selected. The schools were then categorized into 2 groups: mixed day secondary schools on one arm and girls-only/ boys-only boarding secondary schools on the other arm. Each of these arms had an equal number of students. Schools in the 2 sub-counties were picked by sim- 
ple random sampling using a computer-generated randomization list. A sensitization meeting was held in the selected schools with the school administration for ownership, engagement and entry for social mobilization. Subsequently, in each school, students were assessed for study eligibility, selected by simple random sampling and recruited for further interviews.

A mixed method study design was used in the collection of quantitative and qualitative data. The study used surveys, focused group discussions, case narratives and key informant interviews. Use of this mixed method approach allowed for comprehensive triangulation of data and generation of in-depth information to respond to the study objective.

The sample size was determined using Fisher's formula:

$$
n=\frac{z^{2} p q}{e^{2}}
$$

where:

$n=$ required sample size;

$Z=\mathrm{Z}$ score value at $95 \%$ confidence level (standard value of 1.96 );

$p=$ the proposed percentage of students with sexual debut;

$q=1-p$ (variance expected in the responses assumed to be 50:50 proportion rate);

$e=$ Level of precision or margin of error at $\pm 5 \%$ (standard value of 0.05 ).

According to the 2014 Kenya Demographic Health Survey, 50\% of women aged between 20 - 49 years had their first sexual intercourse before the age of 18 years whereas $56 \%$ of men of the same age group had sexual activity before 18 years. Based on these statistics, an average exposure of early sexual intercourse of $50 \%$ was assumed for both girls and boys for purposes of sample size determination.

Therefore,

$$
n=\frac{(1.96)^{2}(0.5)(0.5)}{(0.05)^{2}}=384.16
$$

Rounded off to the next $100=400$.

Thus, $n=400$ respondents.

A sample of 400 students was therefore utilized in this study. Half the students were on the mixed day secondary school arm and the other half on the girls-only and boys-only boarding secondary school arm. Each of the single sex schools had 50 students, while the mixed day secondary schools had 100 students each. In each of these schools, students were randomly selected from a group of students from all levels pooled together. It was however noted that there were fewer participants in the younger age groups. This probably was due to the sensitive nature of the topic under study, resulting in more of the older students who were probably more confident in themselves coming forward and participating in the study.

For the focus group discussions (FGD), purposive sampling was employed to 
select sexually active students identified from the survey. In each school, an FGD comprising of 10 students was conducted. Of note, in each of the 2 mixed day secondary schools, two FGDs for the various sex groups were conducted.

Data were collected over six months between January and June 2019 and entered into a password-protected computer. Self-administered questionnaires were used in the quantitative survey. Qualitative data were tape-recorded and transcribed for analysis. All data were stored in password protected computer. Strict confidentiality was maintained at all times.

Quantitative data were analyzed using SPSS Version 20 statistical software. Qualitative data were transcribed, and analysis was done using a thematic analysis approach with MAXQDA software Version 2018.2.

Authorization to conduct the study in Nyamira County was granted by the National Commission for Science Technology and Innovation (NACOSTI) on 14th July 2018, reference number NACOSTI/P/18/82597/23352. Ethical approval was granted by the Kenyatta National Hospital-University of Nairobi Ethics Committee on 4th October 2018, reference number KNH-ERC/A/362.

\section{Results}

Four hundred students (200 males and 200 females) in mixed day secondary schools and single sex boarding schools were interviewed. Of these 400 students, $244(61 \%)$ were found to have ever had sex. Focused group discussions and case narratives with sexually active students were done. More qualitative data was gotten from key informant interviews.

Most of the students (88.7\%) were aged 16 - 18 years, majority were single (97.5\%) and of the protestant faith (61.3\%). More students in mixed day schools (63.5\%) had ever had sex compared to single-sex schools (58.5\%). However, this was not statistically significant $(p=0.19)$. Male students were more likely than female students to have ever had sex [OR $=1.59$ (95\% CI 0.83, 1.85), $p=0.03$ ]. All of the 10 married students had had sex (Table 1).

In Mixed Day secondary schools, majority of the male (67\%) and female students $(60 \%)$ had ever had sex. Of the younger students (14 - 15 years), majority had not had sex when compared to the older students (16 - 18 years). In all the levels of education, majority of the students had ever had sex. No matter the religion, most of the students had ever had sex. However, only age showed evidence of association with ever having sex $(p=0.04)$. In single sex boarding schools, majority of the boys (66\%) had ever had sex compared to the girls (51\%). On age, apart from the 16-year olds, majority of the students had ever had sex. Only gender was found to be statistically significant with ever having sex $(p=0.03)$ (Table 2).

Key informants were of the opinion that young people were having sex due to the high teenage pregnancy rate in the county.

The education officer in Nyamira South sub-county said:

"It has been happening and it is happening. There are so many cases of tee 
Table 1. Comparison between demographic characteristics of sexually active and non-sexually active in-school adolescents in Nyamira County.

\begin{tabular}{|c|c|c|c|c|c|c|}
\hline & & $\begin{array}{c}\text { Total } n=400 \\
n(\%)\end{array}$ & $\begin{array}{l}\text { No sex } \\
\mathrm{n}(\%)\end{array}$ & $\begin{array}{c}\text { Ever had sex } \\
\text { n (\%) }\end{array}$ & $\begin{array}{l}\text { Odds Ratio } \\
\text { 95\% Confidence Interval }\end{array}$ & $p$-value ${ }^{*}$ \\
\hline \multirow{2}{*}{ School type } & Mixed & $200(50.0)$ & $73(36.5)$ & $127(63.5)$ & 1 & 0.19 \\
\hline & Single boarding & $200(50.0)$ & $83(41.5)$ & $117(58.5)$ & $1.23(0.83-1.85)$ & \\
\hline \multirow{2}{*}{ Gender } & Male & $200(50.0)$ & $67(33.5)$ & $133(66.5)$ & 1 & 0.03 \\
\hline & Female & $200(50.0)$ & $89(44.5)$ & $111(55.5)$ & $1.59(1.06-2.39)$ & \\
\hline \multirow{5}{*}{ Age } & 14 & $23(5.8)$ & $10(43.5)$ & $13(56.5)$ & 1 & 0.03 \\
\hline & 15 & $22(5.5)$ & $10(45.5)$ & $12(54.5)$ & $1.08(0.33-3.51)$ & \\
\hline & 16 & $84(21)$ & $36(42.9)$ & $48(57.1)$ & $0.98(0.38-2.47)$ & \\
\hline & 17 & $150(37.5)$ & $65(43.3)$ & $85(56.7)$ & $0.99(0.41-2.41)$ & \\
\hline & 18 & $121(30.2)$ & 35 (28.9) & $86(71.1)$ & $0.53(0.21-1.32)$ & \\
\hline \multirow{4}{*}{ Education } & Form 1 & $16(4.0)$ & $8(50.0)$ & $8(50.0)$ & 1 & 0.23 \\
\hline & Form 2 & $71(17.8)$ & $26(37.1)$ & $44(62.9)$ & $0.59(0.20-1.76)$ & \\
\hline & Form 3 & $122(30.5)$ & $55(45.1)$ & $67(54.9)$ & $0.82(0.29-2.33)$ & \\
\hline & Form 4 & $191(47.8)$ & $67(34.9)$ & $125(65.1)$ & $0.54(0.19-1.49)$ & \\
\hline Marital & Single & $390(97.5)$ & $156(40.0)$ & $234(60.0)$ & 1 & 0.03 \\
\hline status & Married & $10(2.5)$ & $0(0.0)$ & $10(100.0)$ & $6.62(0.84-52.26)$ & \\
\hline \multirow{3}{*}{ Religion } & Catholic & $144(36.9)$ & $50(34.7)$ & $94(65.3)$ & 1 & 0.20 \\
\hline & Protestant & $239(61.3)$ & $100(41.7)$ & $140(58.3)$ & $1.30(0.85-1.99)$ & \\
\hline & Muslim & $7(1.8)$ & $2(33.3)$ & $4(66.7)$ & $0.92(0.16-5.21)$ & \\
\hline
\end{tabular}

${ }^{*} p$-value is statistically significant at: $p \leq 0.05$ level.

Table 2. Comparison between demographic characteristics of sexually active and non-sexually active in-school adolescents in mixed-day and single-sex boarding secondary schools in Nyamira County.

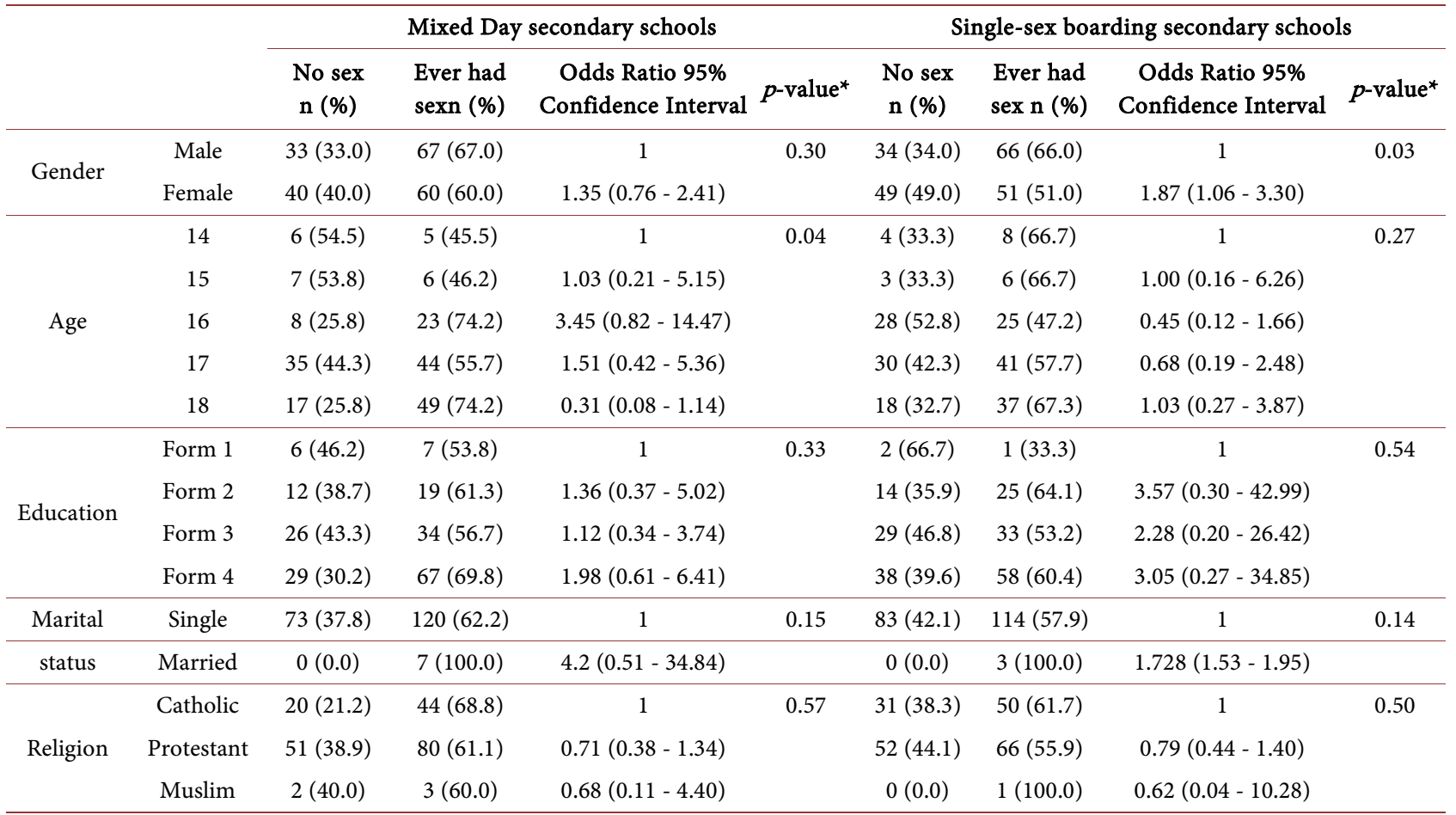

${ }^{*} p$-value is statistically significant at: $p \leq 0.05$ level. 
nage pregnancy. Young mothers dropping out of school is common to a point it's like fashion. Like this year, we had three children sitting the national primary examinations and giving birth and 11 others were pregnant during the national secondary examinations. And we discovered that when you address it, it's like people are not bothered. It's like the way of life." [KII_EO_:18-18(0)]

The community elder said:

"We have cases of young girls becoming pregnant and having children, so that means they are having sex." [KII_Village Elder_70:8-8(0)]

In Table 3, majority of the students 355 (89\%) got their pocket money from their parents, with most of them 247 (62\%) being given less than 500 Kenya shillings (5 U.S. dollars) per month. Ninety nine percent of the students did not engage in work to get extra money. Most of the students 353 (88\%) didn't have sex in-exchange for gifts and of those who did, 37 (89\%) were given money.

Table 3. Economic characteristics of in-school adolescents in Nyamira County, according to school type and gender.

\begin{tabular}{|c|c|c|c|c|c|c|}
\hline & & \multirow{2}{*}{ Total n (\%) } & \multicolumn{2}{|c|}{ School Type } & \multicolumn{2}{|c|}{ Gender } \\
\hline & & & Mixed day & Single sex & Male & Female \\
\hline \multirow{4}{*}{ Source of pocket money } & Parents & $355(88.8)$ & $167(83.5)$ & $188(94.0)$ & $175(87.5)$ & $180(90.0)$ \\
\hline & Relatives & $6(1.5)$ & $4(2.0)$ & $2(1.0)$ & $4(2.0)$ & $2(1.0)$ \\
\hline & Boy/Girlfriend & $17(4.2)$ & $8(4.0)$ & $9(4.5)$ & $1(0.5)$ & $16(8.0)$ \\
\hline & Self-earnings & $22(5.5)$ & $21(10.5)$ & $1(0.5)$ & $20(10.0)$ & $2(1.0)$ \\
\hline \multirow{4}{*}{$\begin{array}{l}\text { Amount given per month } \\
\text { (Kenya shillings) }\end{array}$} & $<500$ & $247(61.8)$ & $140(70.0)$ & $107(53.5)$ & $129(64.5)$ & $118(59.0)$ \\
\hline & $500-1000$ & $88(22.0)$ & $28(14.0)$ & $60(30.0)$ & $39(19.5)$ & $49(24.5)$ \\
\hline & $1000-2000$ & $40(10.0)$ & $17(8.5)$ & $23(11.5)$ & $20(10.0)$ & $20(10.0)$ \\
\hline & $>2000$ & $25(6.2)$ & $15(7.5)$ & $10(5.0)$ & $12(6.0)$ & $13(6.5)$ \\
\hline \multirow{4}{*}{$\begin{array}{l}\text { Occupation of student } \\
\text { (if working) }\end{array}$} & None & $397(99.2)$ & $198(99.0)$ & $199(99.5)$ & $197(98.5)$ & $200(100.0)$ \\
\hline & Business & $1(0.2)$ & $1(0.5)$ & $0(0.0)$ & $1(0.5)$ & $0(0.0)$ \\
\hline & Construction & $1(0.2)$ & $0(0.0)$ & $1(0.5)$ & $1(0.5)$ & $0(0.0)$ \\
\hline & Betting & $1(0.2)$ & $1(0.5)$ & $0(0.0)$ & $1(0.5)$ & $0(0.0)$ \\
\hline \multirow{5}{*}{ Source of presents ${ }^{*}$} & Parents & $237(59.2)$ & $117(58.5)$ & $120(60.0)$ & $165(82.5)$ & $164(49.8)$ \\
\hline & Self & $34(8.5)$ & $21(10.5)$ & $13(6.5)$ & $25(12.5)$ & $9(26.5)$ \\
\hline & Relatives & $8(2.0)$ & $4(2.0)$ & $4(2.0)$ & $4(2.0)$ & $4(50.0)$ \\
\hline & Boy/girlfriend & $29(7.2)$ & $17(8.5)$ & $12(6.0)$ & $6(3.7)$ & $23(79.3)$ \\
\hline & Nobody & $92(23.0)$ & $41(20.5)$ & $51(25.5)$ & $49(24.5)$ & $43(46.7)$ \\
\hline \multirow{2}{*}{ Had sex in exchange for gifts } & Yes & $47(11.8)$ & $13(6.5)$ & $34(17.0)$ & $26(13.0)$ & $21(10.5)$ \\
\hline & No & $353(88.2)$ & $187(93.5)$ & $166(83.0)$ & $174(87.0)$ & $179(89.5)$ \\
\hline \multirow{5}{*}{ If yes, gifts given } & Money & $42(89.4)$ & $19(86.4)$ & $23(92.0)$ & $18(81.8)$ & $24(96.0)$ \\
\hline & Mobile phone & $1(2.1)$ & $1(4.5)$ & $0(0.0)$ & $0(0.0)$ & $1(4.0)$ \\
\hline & Books & $1(2.1)$ & $0(0.0)$ & $1(4.0)$ & $1(4.5)$ & $0(0.0)$ \\
\hline & Food & $1(2.1)$ & $1(4.5)$ & $0(0.0)$ & $1(4.5)$ & $0(0.0)$ \\
\hline & Jewelry & $2(4.3)$ & $1(4.5)$ & $1(4.0)$ & $2(9.1)$ & $0(0.0)$ \\
\hline
\end{tabular}

${ }^{\star}$ Multiple sources of presents. 
The community elder commented on some students having more money. $\mathrm{He}$ said:

"Most of them get money from their parents. The parents give them money for their use. So sometimes they have a lot of money at school. And this is problem." [KII_Village Elder_70: 108-108 (0)]

From focused group discussions, of those who got money from boyfriends and girlfriends, the occupation of their benefactors included bodaboda (motorbike riders), teachers, policemen, supermarket employees, other company employees, brick makers, farmers, those working in hotels, manual jobs, drivers, essentially people with money.

The community elder also commented that:

"You will find young people with the elderly ... sometimes you'll find an old man engaging with girls at school because he has money." [KII_Village Elder _70: 22-22(0)]

Parents had the following comments.

One said:

"Most of them come from poor backgrounds. So maybe the boys may find a girl from a rich family and so they befriend them. So, the girls provide for them." [KII_F_Parent_Nyansabakwa: 4-4 (0)]

Another said:

"Because of the challenges they go through, they decide to look for a man to cater for their needs. And young boys look for women to assist them." [KII_ Parent_F_Bogwendo: 22-22 (0)]

A male student spoke of the older girlfriend paying the bills.

A female student commenting about her former boyfriend said:

"I was engaged to a man who was a policeman working in Sotik. We were in a relationship for five months. He would take me shopping, buy good things for me. He bought me a phone so we could chat. He gave me everything I needed." [CN_F_Bogwendo: 10-10 (0)]

The head of counselling in one of the single sex boarding schools said:

"Sometimes they may come seeking leave from school in the name of seeking for medication and at the end of the day you may realize they are going to see their boyfriends and the parents of the girl are aware because they know they are going to be given something. And some girls would come with sugar or something. Basic needs." [KII_F_G\&C_Bondeka: 22-22 (0)]

The community elder also commented:

"Maybe they buy body lotions ... sometimes the school is very far from home and she walks to school ... she has no means of transport so she uses the money she gets to board a motorbike." [KII_Village Elder_70: 72-72 (0)]

This was collaborated by the sub-county Head of Health. He said:

"The boda boda guys ... they normally lure them with free rides maybe to or from school. So, I think that's why ... they normally take advantage of those girls who cannot afford to pay the boda boda." [KII_MoH: 26-26 (0)]

About the pressure for basic needs, a parent said: 
"You know, sometimes you find there are challenges at home. Maybe there is no food. So, the child decides to look for a man to take care of her, instead of looking for work ... so they go with men who tell them that they don't need to go through challenges. So, the girl accepts to relate with such men and then after 2 or 3 months they become pregnant." [KII_Parent_F_Bogwendo: 33-33 (0)]

The love for nice things also came out. A student from a mixed day secondary school said:

"Even fashion. Other girls have nice clothes and they say it is from their boyfriends. You admire and are tempted. So, you also look for one." [FGD_F_Bogwendo: 62-63 (0)]

A student from a single sex boarding school gave the following as a reason as a reason for having sex:

“Copying other people's lives ... maybe you want to live like they do ... to get good shoes." [FGD_F_Bondeka: 16-16 (0)]

The community elder commented about the current lack of resources and skills by the young people unlike in his earlier years.

The education officer said the lack of concern by parents to pay fees especially for girls drove some of the students to look for benefactors. This was collaborated by a female student during a case narrative.

As illustrated in Table 4, source of presents was the only one found to be associated with ever having sex $(p=0.02)$, with those receiving gifts from boy/girlfriends having four times the odds of ever having sex (OR 4.04, 95\% CI 1.36 - 11.97).

Speaking of rich older people, one male student said:

Table 4. Comparison between economic characteristics of sexually active and non-sexually active in-school adolescents in Nyamira County.

\begin{tabular}{|c|c|c|c|c|c|c|}
\hline & & $\begin{array}{l}\text { Total } \\
\text { n (\%) }\end{array}$ & No sex & Ever had sex & $\begin{array}{c}\text { Odd ratio } \\
95 \% \text { CI }\end{array}$ & $p$-value* \\
\hline \multirow{4}{*}{ Source of pocket money } & Parents & $353(88.7)$ & $144(40.6)$ & $211(59.4)$ & 1 & 0.08 \\
\hline & Relatives & $6(1.5)$ & $2(33.3)$ & $4(66.7)$ & $1.36(0.25-7.55)$ & \\
\hline & Boy/Girlfriend & $17(4.3)$ & $4(23.5)$ & $13(76.5)$ & $2.22(0.71-6.94)$ & \\
\hline & Self-earnings & $22(5.5)$ & $6(27.3)$ & $16(72.7)$ & $1.82(0.70-4.76)$ & \\
\hline \multirow{4}{*}{$\begin{array}{l}\text { Amount given per month } \\
\text { (Kenya shillings) }\end{array}$} & $<500$ & $247(61.8)$ & $99(40.1)$ & $148(59.9)$ & 1 & 0.22 \\
\hline & $500-1000$ & $88(22.0)$ & $38(43.2)$ & $50(56.8)$ & $0.88(0.54-1.44)$ & \\
\hline & $1000-2000$ & $40(10.0)$ & $11(27.5)$ & $29(72.5)$ & $1.76(0.84-3.69)$ & \\
\hline & $>2000$ & $25(6.2)$ & $8(32.0)$ & $17(68.0)$ & $1.42(0.59-3.42)$ & \\
\hline \multirow{5}{*}{ Source of presents } & Parents & $237(59.2)$ & $93(39.2)$ & $144(60.8)$ & 1 & 0.02 \\
\hline & Self & $34(8.5)$ & $13(38.2)$ & $21(61.8)$ & $1.04(0.50-2.18)$ & \\
\hline & Relatives & $8(2.0)$ & $2(25.0)$ & $6(75.0)$ & $1.94(0.38-9.80)$ & \\
\hline & Boy/girlfriend & $29(7.2)$ & $4(13.8)$ & $25(86.2)$ & $4.04(1.36-11.97)$ & \\
\hline & Nobody & $92(23.0)$ & $44(47.8)$ & $48(52.2)$ & $0.70(0.43-1.14)$ & \\
\hline
\end{tabular}

${ }^{*} p$-value is statistically significant at: $p \leq 0.05$ level. 
"For instance, someone from a poor family and they are in boarding school. And today we have sponsors, these rich old guys. They offer good things and one cannot refuse. So that continues until they now start demanding for sex. So, in that case one one finds themselves having sex." [FGD_M_Nyasabakwa (case narrative 1): 43-43 (0)]

The sub-county head of Health commented about the tea bonus. He said:

"You know whenever they have that bonus, they run around with ladies and you find most in lodgings. There are usually problems concerning sexual activity around this area." [KII_MoH: 42-42 (0)]

The village elder thought the young people having a lot of money will predispose them to having sex. He said the converse was also true. He said:

"Sometimes you will find a very young girl ... 9 - 12 engaging in sex because of the poverty." [KII_Village Elder_70: 66-68 (0)]

He spoke of inducement sometimes being simple things like drinks (soda) and lunch.

The head of counselling at Tombe girls boarding school said:

"In some families where they lack funds, over the holidays the girls have sex for money to use at school. Some are provided for by relatives like brothers. So, they have sex with them so as to get money. Sometimes, it's the bread winner and the rule is that they don't disclose. They are threatened that support will be withdrawn if they disclose. And if it is the father then he says if you disclose then he will kill you and the mother." [KII_F_G\&C_Tombe girls: 23-23 (0)]

A female student from a mixed day secondary school said:

"You don't get your daily meals. So, you decide to go to the boyfriend so maybe you get food from there. So, because you need money you engage in sex." [FGD_F_Bogwendo: 58-58 (0)]

Another female student said:

When one does not have money, they may be cheated into sex by men. [FGD_ F_Bondeka: 42-42 (0)]

Another student said:

"When maybe you do not have money. Then you have sex with someone so as to get money." [FGD_F_Rateti: 33-33 (0)]

The education officer said:

"You know Nyamira ... there population is high and increasing steadily. Land is becoming limited. The main activity is agriculture. And as resources become scarce ... this brings about poverty at home because they can no longer farm for economic activities ... the farm is majorly subsistence. So, they need to look for other alternative ways. As a result, there is that pressure on the girl child, not only to meet their basics needs, but to meet their desires to live like other people. And that is why at early stages, sex is seen as pleasure ... but as they grow, it is seen a source of income." [KII_EO_: 40-40 (0)]

In Table 5, in mixed day secondary schools, at least 167 (84\%) students received pocket money from their parents, with most $140(70 \%)$ receiving less than 
500 shillings. Only source of presents showed evidence of an association with ever having sex $(p=0.04)$. In single sex boarding schools, majority of the students 188 (94\%) got their pocket money from their parents, with most students 107 (54\%) receiving less than 500 Kenya shillings. As regards the source of presents, at least 120 (60\%) received from their parents. However, none of these were found to be significantly associated with ever having sex.

Among male in-school adolescents, neither the source of pocket money, the amount given per month nor the source of the presents showed an association with ever having sex. Among female in-school adolescents, source of pocket money and source of the presents were found to be associated with ever having sex, with p-values of 0.04 and 0.02 respectively (Table 6).

\section{Discussion}

This study examined the economic determinants of sexual debut among in-school adolescents in Nyamira county. The main findings of this study were majority of the in-school adolescents (61\%) had ever had sex, with $67 \%$ of male students and $56 \%$ of female students having ever had sex. Most of the students got spending money $(89 \%)$ and gifts $(60 \%)$ from their parents. However, those who received gifts from boy/girlfriends were found to have four times the odds of ever having sex (OR 4.04, 95\% CI 1.36 - 11.97). This suggests that other factors could be at play in early sexual initiation among adolescents such as peer pressure, cultural

Table 5. Comparison between economic characteristics of sexually active and non-sexually active in-school adolescents in mixed-day and single sex secondary schools in Nyamira County.

\begin{tabular}{|c|c|c|c|c|c|c|c|c|c|}
\hline & & \multicolumn{4}{|c|}{ Mixed day secondary schools } & \multicolumn{4}{|c|}{ Single sex boarding schools } \\
\hline & & No sex & $\begin{array}{c}\text { Ever had } \\
\text { sex }\end{array}$ & $\begin{array}{c}\text { Odd ratio } \\
95 \% \mathrm{CI}\end{array}$ & $p$-value & No sex & $\begin{array}{c}\text { Ever had } \\
\text { sex }\end{array}$ & $\begin{array}{c}\text { Odd ratio } \\
95 \% \mathrm{CI}\end{array}$ & $p$-value \\
\hline \multirow{4}{*}{$\begin{array}{c}\text { Source of pocket } \\
\text { money }\end{array}$} & Parents & $63(37.7)$ & $104(62.3)$ & 1 & 0.35 & $81(43.1)$ & $107(56.9)$ & 1 & 0.09 \\
\hline & Relatives & $2(50.0)$ & $2(50.0)$ & $0.61(0.08-4.41)$ & & $0(0.0)$ & $2(100.0)$ & $1.51(0.13-16.99)$ & \\
\hline & Girlfriend & $2(25.0)$ & $6(75.0)$ & $1.82(0.36-9.28)$ & & $2(22.2)$ & $7(77.8)$ & $2.65(0.54-13.09)$ & \\
\hline & Self-earnings & $6(28.6)$ & $15(71.4)$ & $1.51(0.56-4.10)$ & & $0(0.0)$ & $1(100.0)$ & $0.76(0.05-12.29)$ & \\
\hline \multirow{4}{*}{$\begin{array}{l}\text { Amount given per } \\
\text { month } \\
\text { (Kenya shillings) }\end{array}$} & $<500$ & $52(37.1)$ & $88(62.9)$ & 1 & 0.75 & $47(43.9)$ & $60(56.1)$ & 1 & 0.12 \\
\hline & $500-1000$ & $10(35.7)$ & $18(64.3)$ & $1.06(0.46-2.48)$ & & $28(46.7)$ & $32(53.3)$ & $0.90(0.47-1.69)$ & \\
\hline & $1000-2000$ & $6(35.3)$ & $11(64.7)$ & $1.08(0.38-3.10)$ & & $5(21.7)$ & $18(78.3)$ & $2.82(0.98-8.15)$ & \\
\hline & $>2000$ & $5(33.3)$ & $10(66.7)$ & $1.18(0.38-3.65)$ & & $3(30.0)$ & $7(70.0)$ & $1.83(0.45-7.45)$ & \\
\hline \multirow{5}{*}{ Source of presents } & Parents & $39(33.3)$ & $78(66.7)$ & 1 & 0.04 & $54(45.0)$ & $66(55.0)$ & 1 & 0.16 \\
\hline & Self & $7(33.3)$ & $14(66.7)$ & $1.00(0.37-2.68)$ & & $6(46.2)$ & $7(53.8)$ & $0.95(0.30-3.01)$ & \\
\hline & Relatives & $2(50.0)$ & $2(50.0)$ & $0.50(0.07-3.68)$ & & $0(0.0)$ & $4(100.0)$ & $3.27(0.36-30.15)$ & \\
\hline & Boy/girlfriend & $2(11.8)$ & $15(88.2)$ & $3.75(0.82-17.23)$ & & $2(16.7)$ & $10(83.3)$ & $4.09(0.86-19.47)$ & \\
\hline & No body & $23(56.1)$ & $18(43.9)$ & $0.39(0.19-0.81)$ & & $21(41.2)$ & $30(58.8)$ & $1.17(0.60-2.27)$ & \\
\hline
\end{tabular}

${ }^{*} p$-value is statistically significant at: $p \leq 0.05$ level. 
Table 6. Comparison between economic characteristics of sexually active and non-sexually active male and female in-school adolescents in Nyamira County.

\begin{tabular}{|c|c|c|c|c|c|c|c|c|c|}
\hline & & \multicolumn{4}{|c|}{ Male students } & \multicolumn{4}{|c|}{ Female students } \\
\hline & & No sex & $\begin{array}{c}\text { Ever had } \\
\text { sex }\end{array}$ & $\begin{array}{c}\text { Odd ratio } \\
95 \% \text { CI }\end{array}$ & $p$-value & No sex & $\begin{array}{c}\text { Ever had } \\
\text { sex }\end{array}$ & $\begin{array}{c}\text { Odd ratio } \\
95 \% \text { CI }\end{array}$ & $p$-value \\
\hline \multirow{4}{*}{$\begin{array}{l}\text { Source of pocket } \\
\text { money }\end{array}$} & Parents & $60(34.3)$ & $115(65.7)$ & 1 & 0.61 & $84(46.7)$ & $96(53.3)$ & 1 & 0.04 \\
\hline & Relatives & $1(25.0)$ & $3(75.0)$ & $1.57(0.16-15.37)$ & & $1(50.0)$ & $1(50.0)$ & $0.88(0.05-14.21)$ & \\
\hline & Girlfriend & $0(0.0)$ & $1(100.0)$ & $1.04(0.09-11.74)$ & & $4(25.0)$ & $12(75.0)$ & $2.63(0.82-8.45)$ & \\
\hline & Self-earnings & $6(30.0)$ & $6(30.0)$ & $0.52(0.16-1.69)$ & & $0(0.0)$ & $2(100.0)$ & $1.75(0.16-19.65)$ & \\
\hline \multirow{4}{*}{$\begin{array}{l}\text { Amount given per } \\
\text { month } \\
\text { (Kenya shillings) }\end{array}$} & $<500$ & $43(33.3)$ & $86(66.7)$ & 1 & 0.57 & $56(47.5)$ & $62(52.5)$ & 1 & 0.51 \\
\hline & $500-1000$ & $16(41.0)$ & $23(59.0)$ & $0.72(0.34-1.50)$ & & $22(44.9)$ & $27(55.1)$ & $1.11(0.57-2.16)$ & \\
\hline & $1000-2000$ & $5(25.0)$ & $15(75.0)$ & $1.50(0.51-4.40)$ & & $6(30.0)$ & $14(70.0)$ & $2.11(0.76-5.86)$ & \\
\hline & $>2000$ & $3(25.0)$ & $9(75.0)$ & $1.50(0.39-5.83)$ & & $5(38.5)$ & $8(61.5)$ & $1.45(0.45-4.68)$ & \\
\hline \multirow{5}{*}{ Source of presents } & Parents & $37(31.9)$ & $79(68.1)$ & 1 & 0.36 & $56(46.3)$ & $65(53.7)$ & 1 & 0.02 \\
\hline & Self & $10(40.0)$ & $15(60.0)$ & $0.70(0.29-1.71)$ & & $3(33.3)$ & $6(66.7)$ & $1.72(0.41-7.21)$ & \\
\hline & Relatives & $1(25.0)$ & $3(75.0)$ & $1.41(0.14-13.97)$ & & $1(25.0)$ & $3(75.0)$ & $2.58(0.26-25.55)$ & \\
\hline & Boy/girlfriend & $0(0.0)$ & $6(100.0)$ & $2.81(0.33-24.19)$ & & $4(17.4)$ & $19(82.6)$ & $4.09(1.31-12.74)$ & \\
\hline & No body & $19(38.8)$ & $30(61.2)$ & $0.74(0.37-1.48)$ & & $25(58.1)$ & $18(41.9)$ & $0.62(0.31-1.25)$ & \\
\hline
\end{tabular}

${ }^{*} p$-value is statistically significant at: $p \leq 0.05$ level.

norms and popular culture on social media. From the FGDs, the case narratives and the key informant interviews, it came out strongly that due to their need for money for sustenance and/or pleasure, the young people were lured, sometimes forced, to start engaging in sex. This proved the Marxist theory of the effect of the rich on the poor; those with money being able to get sex from those in need of it. For those in need of money for basic needs and upkeep, poverty came out as driver for sexual debut. Similar findings were seen in a study by (Santelli et al., 2015) who found that coming from a poor economic background was associated with early sexual initiation. (Yakubu \& Waliu, 2018) also concluded that poverty was a driver towards early sexual debut and its sequelae.

The study had several strengths. A mixed method study design was employed in the collection of quantitative and qualitative data. Use of this mixed method approach allowed for comprehensive triangulation of data and generation of in-depth information to respond to the study objective. This study too was not subject to loss to follow-up as information from all participants was collected at the same point in time.

There were several limitations in the study. The interviews were conducted by adults on adolescents, among other participants. This might have led to underreporting and misreporting by the adolescents about their sexuality. Adults have been known to admonish adolescents about their sexuality and refusal to abstain from sex (Woods \& Jewkes, 2006). A limitation of trust by the students, that had 
been anticipated, was mitigated by assuring them of utmost confidentiality. This helped minimize information bias.

\section{Conclusion}

Most in-school adolescents in Nyamira county had had their sexual initiation. The factors identified were consistent with the Marxist theory, that those with money had power over one's autonomy and that one's economic environment influenced their decisions. However, a pluralistic environment was also thought to be at play influencing adolescent sexual debut.

\section{Recommendation}

Providing alternate sources of livelihood by government to the people of Nyamira county will help relieve the economic burden and alleviate the pressure put by parents on their children to provide. Efforts also need to be made at school level and at community level to provide sex education to the young people. The Ministry of Education should consider introducing sex education to the school curriculum. This will ensure the adolescents get appropriate and right information for their age-group to inform decision making. The county government of Nyamira needs to encourage churches and non-governmental organizations in the area to work with young people by coming up with youth programs that empower the youth on sexual health and that teach technical skills that will help the young people be able to generate additional income hence removing poverty as a driver towards sexual debut by in-school adolescents.

\section{Acknowledgements}

The authors would like to acknowledge the County Government of Nyamira and the principals of the various secondary schools for facilitating this research.

\section{Conflicts of Interest}

The authors declare no conflicts of interest regarding the publication of this paper.

\section{References}

Ankomah, A., Mamman-Daura, F., Omoregie, G., \& Anyanti, J. (2011). Reasons for Delaying or Engaging in Early Sexual Initiation among Adolescents in Nigeria. Adolescent Health Medicine and Therapeutics, 2, 75-84. https://doi.org/10.2147/AHMT.S23649

County Government of Nyamira (2021). County Demographics. https://www.nyamira.go.ke/about-us?/?c\%20=\%20f8a7bed18e75a98df0218cd728e6d95 $\underline{0}$

Dinkelman, T., Lam, D., \& Leibbrandt, M. (2008). Linking Poverty and Income Shocks to Risky Sexual Behaviour: Evidence from a Panel Study of Young Adults in Cape Town. South African Journal of Economics, 76, 52-74. https://doi.org/10.1111/j.1813-6982.2008.00170.x

Glasier, A., Gülmezoglu, A. M., Schmid, G. P., Moreno, C. G., \& Van Look, P. F. (2006). 
Sexual and Reproductive Health: A Matter of Life and Death. The Lancet, 368, 1595-1607. https://doi.org/10.1016/S0140-6736(06)69478-6

Kastbom, A. A., Sydsjö, G., Bladh, M., Priebe, G., \& Svedin, C. G. (2015). Sexual Debut before the Age of 14 Years Leads to Poorer Psychosocial Health and Risky Behaviour in Later Life. Acta Paediatrica, 104, 91-100. https://doi.org/10.1111/apa.12803

Kenya National Bureau of Statistics (2015). Kenya Demographic and Health Survey 2014. Calverton, Maryland: KNBS and ICF Macro.

Santelli, J. S., Song, X., Holden, I. K., Wunder, K., Zhong, X., Wei, Y., Mathur, S., Lutalo, T., Nalugoda, F., Gray, R. H., \& Serwadda, D. M. (2015). Prevalence of Sexual Experience and Initiation of Sexual Intercourse among Adolescents, Rakai District, Uganda, 1994-2011. Journal of Adolescent Health, 57, 496-505.

https://doi.org/10.1016/j.jadohealth.2015.07.018

Speizer, I. S., Fotso, J. C., Davis, J. T., Saad, A., \& Otai, J. (2013). Timing and Circumstances of First Sex among Female and Male Youth from Select Urban Areas of Nigeria, Kenya, and Senegal. Journal of Adolescent Health, 53, 609-616.

https://doi.org/10.1016/j.jadohealth.2013.06.004

Wood, K., \& Jewkes, R. (2006). Blood Blockages and Scolding Nurses: Barriers to Adolescent Contraceptive Use in South Africa. Reproductive Health Matters, 14, 109-118. https://doi.org/10.1016/S0968-8080(06)27231-8

Yakubu, I., \& Salisu, W. J. (2018). Determinants of Adolescent Pregnancy in Sub-Saharan Africa: A Systematic Review. Reproductive Health, 15, Article No. 15. https://doi.org/10.1186/s12978-018-0460-4 